\title{
NOMADISM IN LARGE FALCONS: LESSONS FROM THE SAKER FALCON IN MONGOLIA
}

\author{
David H. ElLIS ${ }^{1}$, Ignacy KITOWSKI ${ }^{2}$, AND TerRy B. Roundy ${ }^{3}$ \\ ${ }^{1}$ Institute for Raptor Studies, 3722 E. Defiance Street, \\ Oracle, AZ 85623, USA. E-mail: dcellis@ theriver.com \\ ${ }^{2}$ Department of Zoology, University of Life Sciences in Lublin, Akademicka 13, \\ 20-950 Lublin, Poland
}

${ }^{3} 602$ East 500 South, Bountiful, UT 84010, USA

\begin{abstract}
Nesting density of Saker Falcons (Falco cherrug) in some regions of Mongolia were found to fluctuate dramatically over the years. Very few eyries were consistently occupied year after year. These observations suggest that many Sakers leave one territory, move long distances, and establish new territories. The most likely explanation for this nomadism is instability of food sources (i.e., regional peaks and valleys in populations of small rodents). Other demographic traits suggesting nomadism include the mid-summer absence of adults in territories occupied earlier in the spring, asynchronous breeding (i.e., a high proportion of late clutches), abandonment of eggs, more frequent use of marginal sites (e.g., ground nests) in zones of high prey density, and, in the long term, low occupancy rates of poor sites. The data for Mongolia suggest that the Saker Falcon exhibits partial nomadism when local prey populations fluctuate widely. More severe fluctuations in prey density in Australia favor complete nomadism for some subpopulations of the Black Falcon (F. subniger). Wide scale prey crashes and the persistence of alternate prey in the Arctic seldom favor nomadism in the Gyrfalcon (F. rusticolus). However, the effects of global warming on Gyrfalcon prey are likely to promote nomadism in the future. Received 24 February 2011, accepted 28 June 2011.
\end{abstract}

Ellis, D. H., I. KitowsKi, AND T. B. Roundy. 2011. Nomadism in large falcons: Lessons from the Saker Falcon in Mongolia. Pages 291-306 in R. T. Watson, T. J. Cade, M. Fuller, G. Hunt, and E. Potapov (Eds.). Gyrfalcons and Ptarmigan in a Changing World, Volume II. The Peregrine Fund, Boise, Idaho, USA. http://dx.doi.org/10.4080/gpcw.2011.0307

Key words: Demography, Falco cherrug, nomadism, Saker.

PRIOR TO 1970, Saker Falcon (Falco cherrug) records for Mongolia accumulated largely as incidental observations made along the track of research expeditions. The Saker was first reported in Mongolia in the travels of Przewal- ski (1876 in Shagdarsuren 2000) and was frequently reported in ornithological expeditions thereafter. These early expeditions have been summarized by Piechocki (1983). Raptor surveys in Mongolia have been summarized by 
Meyburg and Meyburg (1983). Baumgart $(1978,1980)$ studied a few pairs of nesting Sakers and Shagdarsuren (2000) recounted other minor efforts to study the species.

Extensive and intensive research began in 1994 (Ellis 2001, 2010) with a Mongolia-wide study of Saker ecology. From this work (19942008), we learned that the species exists in sizable numbers from extreme western to extreme eastern zones, that it is common in grassland, dry steppe, and montane steppe habitat, and that it is sparsely distributed in forest edge and desert habitats. Cliff nesting is common, but many pairs use trees and many use artificial structures (e.g., powerline support structures: Ellis 2010, Ellis et al. 1997, 2001, Potopov et al. 2001a).

This paper explores unusual demographic features favoring partial nomadism in Saker populations in Mongolia. We also hypothesize explanations for more complete nomadism in the Black Falcon (F. subniger) and the reported lack of nomadism in the Gyrfalcon (F. rusticolus).

Most knowledge of raptor population dynamics is based on eyrie occupancy and productivity levels. Further, most raptor management decisions for rare raptors are based on the assumption that breeding territories are persistent. If a territory is vacant, the pair is treated mathematically as if lost. Indeed, the typical response to low prey densities for most raptors is to reproduce poorly, not to emigrate. However, for nomadic species, site occupancy rates reveal almost nothing about population size. For such species, when breeding sites are vacant, locally or regionally, the net number of birds for that species may not have decreased: the birds are simply elsewhere.

In one sense, all but sessile consumers (and therefore all raptors) become nomadic when food is scarce. Nomadism is traditionally characterized as wide scale movement of a forager following its food supply (Allen and Saunders 2002). In winter, migratory raptors typically wander in search of food, so in another sense, many raptors are nomadic, at least in winter. However, nomadism in birds, as discussed here, involves breeders leaving behind their former territory and moving long distances to breed in a new area (Andersson 1980). Potapov et al. (2000, 2001b, 2001c, 2002, Sumiya et al. 2001) conducted radio telemetry studies of Saker home ranges in Mongolia and looked at migratory movements, but these efforts shed no light on nomadism of breeding pairs as described here. Nomadism is most commonly associated with foragers having a narrow feeding niche and living in vast arid environments. Use of many food sources lessens the need to follow irruptions of a single prey species, so for most raptors, breeding site fidelity is high.

For raptors, summer nomadism is best known for a few species of owls (Clark 1975, Parmelee 1992, Hipkiss et al. 2002, Wiggins et al. 2006) and Falconiformes, such as the Rough-legged Hawk (Buteo lagopus) and some small falcons (Galushin 1974), all of which are dependent on irruptive prey. Regional population nadir events (apparently due to non-availability of prey) have been documented (Whitaker et al. 1996, Bechard and Swem 2002). The best example of nomadism in large falcons is probably the Black Falcon, for which whole populations apparently move from region to region following their prey, which in turn follow the rains (Ferguson-Lees and Christie 2001).

Here we will evaluate trends for Saker Falcon site occupancy and productivity across Mongolia. Although Galushin (1974) stated that the Saker is not nomadic, and indeed many Saker populations may not be nomadic, some previous publications reveal traits that suggest nomadism in the Saker. These include studies of reproductive performance (Ellis et al. 1996), unusual breeding situations (Ellis et al. 1997), and siblicide (Ellis et al. 1999). Corollary work, conducted by biologists financed primarily by the National Avian Research Center 
(NARC) of the United Arab Emirates, was reported in a volume edited by Banzragch et al. (2001) and in the newsletter of the Middle East Falcon Research Group available online at www.savethesaker.com.

\section{MeTHODS}

In six expeditions $(1994,1995,1997,1998$, 2000 , and 2008), we traversed much of the steppe and foothill habitat from extreme eastern to extreme western Mongolia. We did not search the forests of the north-central region nor the drier portions of the Gobi Desert in south-central and southwestern Mongolia. Because Mongolia, even today, is largely without fences (except along the railroads), and developed roads are very few, we were able to course at will across the landscape searching for falcon eyries. Each year, a team of three or four persons in a single $4 \mathrm{WD}$ vehicle traversed $3,000-5,400 \mathrm{~km}$.

Although we did not quantitatively measure prey density on any expedition, we did note areas of rodent and lagomorph abundance, so we are able to hypothesize explanations for the falcon distribution patterns we observed.

Our method during the first two years was to drive in a general direction, then divert left and right when likely raptor nesting habitat appeared on the horizon. In subsequent years, we retraced parts of our 1994 and 1995 routes and revisited most sites found in previous expeditions, but we also deviated in search of additional pairs.

We classed breeding areas as follows: known breeding sites were places where eggs or young (live or dead) were seen or where one or more adults were observed incubating, brooding, or feeding young. We sometimes concluded that birds were breeding by adult behavior alone. Probable breeding sites were those with a likely nesting structure attended by an adult perched nearby or defending but where we did not observe eggs or young, incu- bation, brooding, or feeding. We classified a few situations as former breeding sites: here feathers, eggshells, excrement, or skeletal remains indicated Sakers once bred here but live birds were absent. To avoid unduly inflating territory totals when reporting site occupancy, we tallied a new site only if a pair was found further than $2 \mathrm{~km}$ from an old eyrie. The only exception to this rule was in 2008 when we found two pairs during the same year within $2 \mathrm{~km}$ of each other.

Fledging rates were estimated from observations of large nestlings (i.e., $\geq 10$ days of age) or recently fledged juveniles. If, at a site, birds were fledged, we examined the area for excrement, prey remains, and molted down to identify the eyrie location. For sites where the youngest bird was flying well, we would normally be uncertain of the number of young fledged, so productivity was reported as $\geq n$ ( $\mathrm{n}=$ the number of fledged young observed). Eyries with eggs or tiny young were counted as being probably successful only if closely attended by an adult; however, we did not use information from the early nesting stages in estimating the number of young fledged per eyrie. Data from early in the nesting season were used only in reporting eyrie occupancy rates, clutch sizes, and eyrie descriptions.

In 1994-1995, we entered most eyries to count young, implant PIT tags, take blood samples, measure nest sites, etc. (Ellis et al. 1996). When parents were incubating or brooding small young (especially on sunny or snowy days), we often did not enter eyries and thereby avoided jeopardizing progeny. Also, for electric power poles and towers, we entered only a sample of eyries, and these primarily to take measurements, which we subsequently used in describing nests on similar towers and poles.

Nesting phenology was estimated by aging chicks. When it was possible to enter and exit an eyrie quickly during the incubating/brooding stage, we often did so, but all estimates of 
hatching dates came, not from examining eggs (except hatching eggs), but from comparing nestling development with the Moritsch (1983) aging guide for Prairie Falcons (Falco mexicanus). For many nestlings, we also measured wing chord. However, a large number of the nestlings in our study were viewed only from afar, so for these we used only Moritsch's photographs. The hatch date values presented here were estimated from the age of the oldest nestling (i.e., the nestling with the most advanced plumage) while being aware that males (smaller) develop more quickly. For birds in the nest, our estimates were known (for the few cases when we knew hatch date) to be accurate within \pm 3 days.

If the young had recently fledged at the time of our visit, we assigned an age of 45-50 days to the youngest bird if it still had a conspicuously short tail and rounded wings. In estimating the age of the oldest bird, we then added two days. If all birds showed pointed wings and long tails, we merely stated that the oldest bird was $>10$ days out of the nest and estimated no hatch date.

\section{Results}

Figure 1 illustrates the distribution of 201 Saker territories (231 specific eyries) across Mongolia. Because population parameters varied locally, we further subdivided some regions for reporting occupancy and productivity (Table 1).

During our early work, we were surprised and alarmed to see how infrequently breeding territories were occupied year after year (Table 1). For example, in 2008, only 12 of 21 known sites in the Henti Mountain foothills were occupied. In the South-Central Grasslands, only 19 of 33 known sites were occupied. Such low site occupancy rates for other species have been used to describe population collapse events (Hickey and Roelle 1969). However, when we compared the number of sites occupied from year to year over large regions, it became apparent that a wide scale population decline had not occurred: rather it appeared that birds were moving from area to area. Further, in most areas, reproductive output per pair remained high even if occupancy was low.

The most fundamental indicators of nomadism are high rates of adult immigration and emigration. Lacking data on individual birds, we look in Table 1 at vast changes in population size by region. Such changes are most evident for regions C and D. In the Northeast Grasslands, the rate of site occupancy varied from one territory in 14 known territories in 1998 to 14 in 16 in 2008. These differences are statistically significant (Fisher exact test, (one cut): $\mathrm{P}<0.0001)$. Along with the dramatic rise in the population, 13 of 16 sites were productive in 2008, but only one in 14 in 1998 . These differences are highly significant (Fisher exact test, (one cut): $\mathrm{P}<0.0001)$. The South-central Grasslands (Western Portion) followed the same trends for the same years. There in 1998, we found eight territories occupied of 31 known, while in 2008, we documented 19 occupied of 33 known. These differences again were significant (Fisher exact test (one cut): $\mathrm{P}=0.0098)$.

So where was the source population? Of course, our numbers represent only a fraction of the eyries in our study areas, and the best comparisons would be for sequential years, not for multi-year spans. That said, obvious sources for the increase in breeders in one area are the progeny from previous years and itinerant adults.

Other evidence for nomadism is that many individual eyries (especially marginal sites) are only intermittently occupied. In Table 2 , we show occupancy rates for 34 eyries in two zones. The Saker data should be considered in the light that occupancy rates for some populations of the non-nomadic Peregrine (Falco peregrinus) (ironically the name "peregrine" translates as "wanderer") approach $100 \%$ (Cade et al. 1988). For the Saker, however, we 


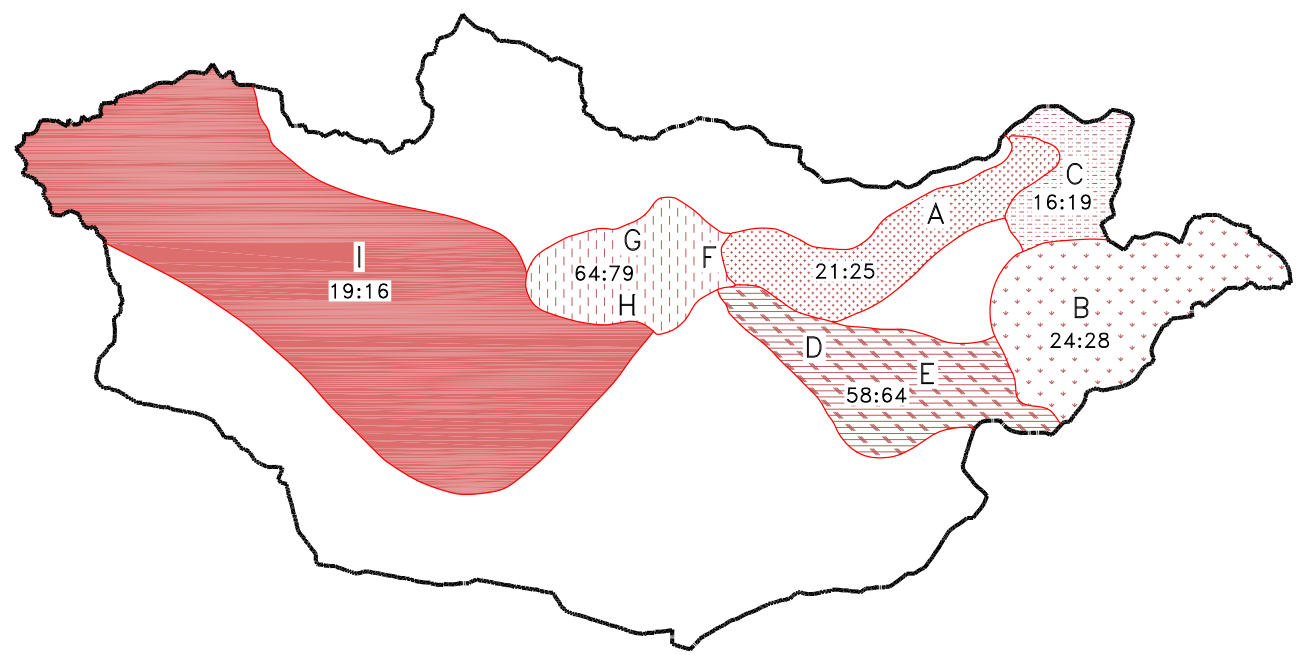

Figure 1. Saker study regions, Mongolia.

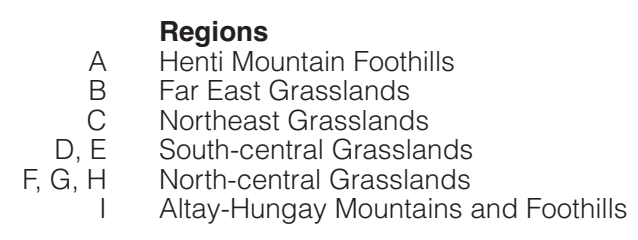

see that, in zone B, where the population was more stable than for any other zone, only eight territories (in 18) were occupied every year. When we consider one of the least stable populations, area C, only one eyrie (in 16) was occupied every year.

Another indicator of nomadism is the frequent use of marginal nesting sites when prey is abundant locally. A quantitative eyrie-by-eyrie evaluation of the suitability of nest sites is beyond the scope of this paper, but in other publications (Ellis et al. 1997, 2009, 2010), we described ground nesting and use of various novel nesting supports, including ruins of buildings, boulders, and rocky hillsides (see also Potapov et al. 2001a, Stubbe et al. 2010). Nests on many of these substrates are extremely vulnerable to predation. From gross inspection, it does appear that the most vulnerable eyries are the ones occupied only when prey is abundant.

For some raptors, it is possible to predict prey availability prior to the time of nesting: for oth-

$\begin{array}{cc}\text { No. Territories } & \text { No. Eyries } \\ 21 & 25 \\ 24 & 28 \\ 16 & 19 \\ 58 & 64 \\ 64 & 79 \\ 19 & 16\end{array}$

ers, the pair must make the investment in producing a clutch of eggs before prey abundance and availability can be assessed (Newton 1979:98). Sakers appear to be in the latter category, for we have found, through the years, several abandoned clutches of eggs and a few abandoned broods of tiny chicks (see also Bold and Boldbaatar 2001). Such finds are sometimes accidental: for these, eggs or dead chicks were found as we clambered about inspecting trees, cliffs, etc. that showed limited signs of occupancy. Twice we found abandoned Saker eggs buried under fresh nesting materials in Upland Buzzard (Buteo hemilasius) nests. Gombobaatar et al. (2004) also documented high rates of egg desertion (and hatching failure and chick mortality) in their study area, also in Mongolia. We systematically searched vacant, small cliffs in each region, but how many more abandoned eggs and young might have been found had all the large cliffs been scoured and had we climbed to every seemingly unused nest on every powerline tower? 
Table 1. Occupancy and productivity rates for Sakers in nine regions of Mongolia. ${ }^{1}$

\begin{tabular}{|c|c|c|c|c|c|c|c|c|}
\hline & & rameter $^{2}$ & $1994^{3}$ & 1995 & 1997 & 1998 & 2000 & 2008 \\
\hline Henti Mt. Foothills & $A^{4}$ & $\begin{array}{l}\text { Occupancy/All } \\
\text { Productivity/All } \\
\text { Productivity/Occupancy }\end{array}$ & $\begin{array}{l}\text { N.A. } \\
\text { N.A. } \\
\text { N.A. }\end{array}$ & $\begin{array}{l}9 \mathrm{~N} \\
\text { N.D. } \\
9 / 9\end{array}$ & $\begin{array}{l}11 / 15 \\
7 / 15 \\
7 / 11\end{array}$ & $\begin{array}{l}7 / 15 \\
4 / 15 \\
4 / 7\end{array}$ & $\begin{array}{l}\text { N.A. } \\
\text { N.A. } \\
\text { N.A. }\end{array}$ & $\begin{array}{l}12 / 21 \\
8 / 21 \\
8 / 12\end{array}$ \\
\hline Far E Grasslands & B & $\begin{array}{l}\text { Occupancy/All } \\
\text { Productivity/All } \\
\text { Productivity/Occupancy }\end{array}$ & $\begin{array}{l}\text { N.A. } \\
\text { N.A. } \\
\text { N.A. }\end{array}$ & $\begin{array}{l}14 \mathrm{~N} \\
\text { N.D. } \\
11 / 14\end{array}$ & $\begin{array}{l}15 / 18 \\
12 / 18 \\
12 / 15\end{array}$ & $\begin{array}{l}12 / 19 \\
10 / 19 \\
10 / 12\end{array}$ & $\begin{array}{l}\text { N.A. } \\
\text { N.A. } \\
\text { N.A. }\end{array}$ & $\begin{array}{l}15 / 22 \\
6 / 21 \\
6 / 15\end{array}$ \\
\hline NE Grasslands & C & $\begin{array}{l}\text { Occupancy/All } \\
\text { Productivity/All } \\
\text { Productivity/Occupancy }\end{array}$ & $\begin{array}{l}\text { N.A. } \\
\text { N.A. } \\
\text { N.A. }\end{array}$ & $\begin{array}{l}5 \mathrm{~N} \\
\text { N.D. } \\
4 / 5\end{array}$ & $\begin{array}{l}2 / 10 \\
1 / 10 \\
1 / 2\end{array}$ & $\begin{array}{l}1 / 14 \\
1 / 14 \\
1 / 1\end{array}$ & $\begin{array}{l}\text { N.A. } \\
\text { N.A. } \\
\text { N.A. }\end{array}$ & $\begin{array}{l}14 / 16 \\
13 / 16 \\
13 / 14\end{array}$ \\
\hline $\begin{array}{l}\text { SC Grasslands } \\
\text { (Western Portion) }\end{array}$ & $\mathrm{D}$ & $\begin{array}{l}\text { Occupancy/All } \\
\text { Productivity/All } \\
\text { Productivity/Occupancy }\end{array}$ & $\begin{array}{l}\text { N.A. } \\
\text { N.A. } \\
\text { N.A. }\end{array}$ & $\begin{array}{l}9 \mathrm{~N} \\
\text { N.D. } \\
8 / 8\end{array}$ & $\begin{array}{l}5 / 18 \\
1 / 18 \\
1 / 5\end{array}$ & $\begin{array}{l}8 / 31 \\
8 / 31 \\
8 / 8\end{array}$ & $\begin{array}{l}\text { N.A. } \\
\text { N.A. } \\
\text { N.A. }\end{array}$ & $\begin{array}{l}19 / 33 \\
19 / 33 \\
19 / 19\end{array}$ \\
\hline $\begin{array}{l}\text { SC Grasslands } \\
\text { (Eastern Portion) }\end{array}$ & $E$ & $\begin{array}{l}\text { Occupancy/All } \\
\text { Productivity/All } \\
\text { Productivity/Occupancy }\end{array}$ & $\begin{array}{l}\text { N.A. } \\
\text { N.A. } \\
\text { N.A. }\end{array}$ & $\begin{array}{l}10 \mathrm{~N} \\
\text { N.D. } \\
8 / 10\end{array}$ & $\begin{array}{l}12 / 18 \\
12 / 18 \\
11 / 12\end{array}$ & $\begin{array}{l}13 / 18 \\
10 / 18 \\
10 / 13\end{array}$ & $\begin{array}{l}\text { N.A. } \\
\text { N.A. } \\
\text { N.A. }\end{array}$ & $\begin{array}{l}8 / 20 \\
8 / 20 \\
8 / 8\end{array}$ \\
\hline $\begin{array}{l}\text { NC Grasslands } \\
\text { (Southeastern Portion) }\end{array}$ & $F$ & $\begin{array}{l}\text { Occupancy/All } \\
\text { Productivity/All } \\
\text { Productivity/Occupancy }\end{array}$ & $\begin{array}{l}1 \mathrm{~N} \\
\text { N.D. } \\
1 / 1\end{array}$ & $\begin{array}{l}2 / 2 \\
2 / 2 \\
2 / 2\end{array}$ & $\begin{array}{l}12 / 29 \\
11 / 29 \\
11 / 12\end{array}$ & $\begin{array}{l}16 / 28 \\
16 / 28 \\
16 / 16\end{array}$ & $\begin{array}{l}14 / 28 \\
13 / 28 \\
13 / 14\end{array}$ & $\begin{array}{l}14 / 31 \\
4 / 31 \\
4 / 14\end{array}$ \\
\hline $\begin{array}{l}\text { NC Central } \\
\text { Grasslands } \\
\text { (Western Portion) }\end{array}$ & G & $\begin{array}{l}\text { Occupancy/All } \\
\text { Productivity/All } \\
\text { Productivity/Occupancy }\end{array}$ & $\begin{array}{l}\text { N.A. } \\
\text { N.A. } \\
\text { N.A. }\end{array}$ & $\begin{array}{l}\text { N.A. } \\
\text { N.A. } \\
\text { N.A. }\end{array}$ & $\begin{array}{l}\text { N.A. } \\
\text { N.A. } \\
\text { N.A. }\end{array}$ & $\begin{array}{l}\text { N.A. } \\
\text { N.A. } \\
\text { N.A. }\end{array}$ & $\begin{array}{l}6 \mathrm{~N} \\
\text { N.D. } \\
3 / 5\end{array}$ & $\begin{array}{l}9 / 11 \\
9 / 11 \\
9 / 9\end{array}$ \\
\hline $\begin{array}{l}\text { NC Grasslands } \\
\text { (Red Steppe) }\end{array}$ & $\mathrm{H}$ & $\begin{array}{l}\text { Occupancy/All } \\
\text { Productivity/All } \\
\text { Productivity/Occupancy }\end{array}$ & $\begin{array}{l}2 \mathrm{~N} \\
\text { N.D. } \\
2 / 2\end{array}$ & $\begin{array}{l}9 / 10 \\
9 / 10 \\
9 / 9\end{array}$ & $\begin{array}{l}6 / 12 \\
1 / 12 \\
1 / 6\end{array}$ & $\begin{array}{l}6 / 15 \\
3 / 14 \\
3 / 5\end{array}$ & $\begin{array}{l}6 / 12 \\
5 / 12 \\
5 / 6\end{array}$ & $\begin{array}{l}9 / 14 \\
7 / 13 \\
7 / 8\end{array}$ \\
\hline $\begin{array}{l}\text { Altay/Hangay } \\
\text { Mountains and } \\
\text { Foothills }\end{array}$ & I & $\begin{array}{l}\text { Occupancy/All } \\
\text { Productivity/All } \\
\text { Productivity/Occupancy }\end{array}$ & $\begin{array}{l}19 \mathrm{~N} \\
\text { N.D. } \\
16 / 16\end{array}$ & $\begin{array}{l}\text { N.A. } \\
\text { N.A. } \\
\text { N.A. }\end{array}$ & $\begin{array}{l}\text { N.A. } \\
\text { N.A. } \\
\text { N.A. }\end{array}$ & $\begin{array}{l}\text { N.A. } \\
\text { N.A. } \\
\text { N.A. }\end{array}$ & $\begin{array}{l}\text { N.A. } \\
\text { N.A. } \\
\text { N.A. }\end{array}$ & $\begin{array}{l}\text { N.A. } \\
\text { N.A. } \\
\text { N.A. }\end{array}$ \\
\hline
\end{tabular}

${ }^{1}$ Some values in table do not match values elsewhere in the table or in Figure 1 because all eyries were not visited each year and results from a small number of visits were uncertain (e.g., molted feathers may lead to conclusions of occupancy, but it may be unclear if young fledged, so site contributes to occupancy values but not productivity).

${ }^{2}$ Abbreviations are: Occupancy/All - number of territories occupied/total number of territories visited and evaluated for occupancy; Productivity/All - number of sites which probably fledged young (i.e., sites with live, healthy young plus sites where adults where incubating eggs or brooding or feeding chicks)/number of territories evaluated for occupancy; Productivity/Occupancy - number of sites projected to fledge young/number of sites occupied in region.

${ }^{3}$ N.A. - not applicable: area not visited; N.D. and N - not defined (N.D.) and N (new: e.g., 9 N in 1995, top row $=9$ new sites found). For each zone, the first survey year Occupancy/All and Productivity/All rates are not comparable with rates for subsequent years, because the newly found sites have not had a chance to be unoccupied. However, ratio vales for Productivity/Occupancy are comparable and so are supplied in the table.

${ }^{4} \mathrm{~A}-\mathrm{I}$ are zones identified in Figure 1.

The germane question is this: do Saker pairs (or individual adults) abandon one territory and move to a new one the same year? Bold and Boldbaatar (2001) claimed that in poor vole years, falcons breed but fail to fledge young, rather than move to zones of higher prey concentration as our data suggest. We have no direct evidence for the movement of individual birds, but we do have considerable indirect evidence. First, for most sites with abandoned eggs or chicks (mentioned above), Sakers were absent and Ravens (Corvus corax) or buzzards were sometimes present. We suspect that adults at these sites had moved to zones with higher prey populations. Also, each year we found that some pairs of Sakers were 


\section{Estimated hatch dates for Saker Falcons}
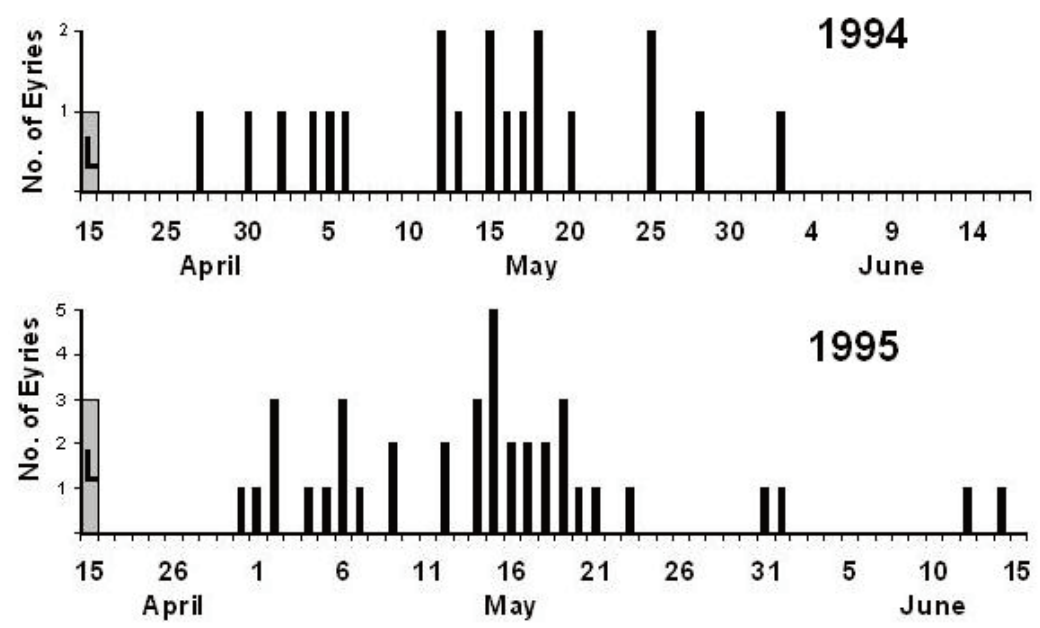

Figure 2. Estimated hatch dates for Saker Falcons. L (gray column at 15 April) represents eyries where hatch date was prior to 16 April but lay date was uncertain because young were fledged at least 10 days prior to our visit.

Table 2. Occupancy rates for individual territories in one stable and one unstable population of Sakers in Mongolia. ${ }^{1}$

\begin{tabular}{|c|c|c|c|c|c|c|c|c|c|}
\hline \multirow[t]{2}{*}{ Zone } & \multirow{2}{*}{$\begin{array}{l}\text { No. of Territories } \\
\text { Included }\end{array}$} & \multirow[b]{2}{*}{$1 / 4$} & \multirow[b]{2}{*}{$1 / 3$} & \multirow[b]{2}{*}{$1 / 2$} & \multicolumn{3}{|c|}{ Occupancy Rates ${ }^{2}$} & \multirow[b]{2}{*}{$3 / 3$} & \multirow[b]{2}{*}{$4 / 4$} \\
\hline & & & & & $2 / 4$ & $2 / 3$ & $3 / 4$ & & \\
\hline B Stable & 18 & 1 & 3 & 0 & 2 & 1 & 3 & 0 & 8 \\
\hline C Unstable & 16 & 0 & 5 & 7 & 3 & 0 & 0 & 1 & 0 \\
\hline
\end{tabular}

${ }^{1}$ Zones are mapped in Fig. 1.

2Occupancy rate values translate as follows: $1 / 4=$ this territory was checked for occupancy for four years and found active in only 1 of these years.

nesting up to two months later than others (Figure 2). Are the late pairs immigrants (nomads) that have failed elsewhere? At temperate latitudes, breeding pairs of most raptor species are typically in close synchrony (Newton 1979:95). The asynchrony seen in Figure 2, especially the late May and early June hatch dates, strongly suggests renesting.

\section{Discussion}

Monitoring Populations. - If, as observations from Mongolia suggest, some Sakers are nomadic, how can we monitor such mobile populations for conservation purposes? An obvious conclusion is that censuses of breeding pairs must involve large regions and dozens of breeding sites. Such efforts are labor intensive, so we ask: are there less involved "indices" to population trends?

One such indicator is the presence of a remnant breeding population even during prey nadirs. We observed that even in zones where and when a large segment of the population was gone, a few pairs, mostly those at the more secure breeding sites and sites with presumably dependable prey, remained to be counted.

Some other likely indicators that help determine the cause of a Saker population crash follow. If trapping for falconry were the decimating factor, many eyrie sites should be occupied by lone males (Arab falconry involves mostly females). If a falcon population has immigrated to a zone with more abun- 
dant prey, it should be possible to locate prey concentration zones and search there for falcons. If such searches fail, it is likely that the entire population has been reduced by some large-scale mortality factor such as rodenticides (see below).

Other indicators of an overharvest for falconry are population levels of other raptors. Falcon trappers typically try to kill all the eagles in the trapping zone so the eagles will not kill falcons in the traps. In addition, trappers feed the falcons they trap on eagle flesh (Upton 2002:75). The presence of high nesting densities of Upland Buzzards in zones with no or few nesting Sakers also suggests an overharvest for falconry. If a Saker low coincides with a buzzard low, falcon trapping is less likely the cause.

Regional Changes in the Number of Nests and Nest Support Structures.-In studies of the ecology of large falcons, the number of breeding sites available in a region is usually fairly constant. In Mongolia, the opposite is true. In many parts of the world, large falcons often nest in soil on ledges, so they do not require nests built by other birds. Not so Mongolia: of 231 Saker eyries examined so far, fewer than 10 were not in stick nests. In relating occupancy and productivity rates to nomadism, we faced the complication that nests, and sometimes nest support structures do not last long.

This is both a natural and an artificial phenomenon. Tree nests used by Sakers very often fall after a year or two. When last year's nest was gone, we searched the vicinity for other nests before reporting a site unoccupied. During this study, we found some electric utility support structures, including metal power transmission towers, removed. However, numerically, the most important nest-destroying factors were wind and/or humans removing nests from powerlines. Gombobaatar et al. (2004) found that nest destruction along powerlines accounted for $10 \%$ of egg losses from 1998-2004.
The productivity values that we believe were altered most significantly by nest destruction were for the North-central Grasslands (Southeast portion) for 2008. There (Table 1: F), we found 14 sites occupied but only four productive. Falcons were still present at 10 sites where nests had recently been destroyed (by wind or humans).

Surprisingly, even buildings scattered across the Mongolian steppe were often temporary. We sometimes found Sakers nesting on abandoned railroad outbuildings and well houses. None of the buildings used from 1995-1998 were occupied in 2008: most had been pounded to rubble. To offset this problem, and because of the availability of vast reaches of Mongolia where prey was sufficient but suitable nesting supports were lacking, we created 150 artificial eyries from 1997 to 2000 (Ellis et al. 1998, 2001). Most of our nests were wired to metal power transmission towers so the wind could not remove them. Falcons could use these immediately, but more often Ravens, Upland Buzzards, and other raptors enlarged our foundations. Sakers thereafter confiscated the nests, seemingly at will. Some continued to be occupied by Sakers to the present (Ellis et al. 2010). Environment Agency Abu Dhabi-financed teams are now building artificial nests by the thousands (Dixon et al. 2011). Obviously the addition of many artificial nests and their use by Sakers would inflate occupancy rates in that region.

The Impact of Falconry.-Across its vast breeding range, from Hungary in the west to Manchuria in the east, from southern Siberia in the north to the Tibetan Plateau and Iran in the south, the Saker is subject to many population limiting factors in addition to prey fluctuations. The Saker Falcon is probably the only raptor to have been locally extirpated and regionally endangered due to harvest for falconry (Levin 2001, Barton 2002, Gombobaatar et al. 2004). While our data show that sizable populations still exist in some regions of Mongolia, in other regions, populations are reported to have 
collapsed (Banzragch et al. 2001), and even been extirpated (Barton 2002).

Levin $(2000,2001)$ reported that, nationwide, the Saker population in adjacent Kazakhstan plummeted from 3000-5000 pairs to $100-400$ pairs in only five years. Research in Kazakhstan financed by Saudi Arabia began in 1992, but Levin (2001:68) reported “....in reality it was set to cover up illegal export of the falcons." In closing, Levin (2001) stated that "while making... speeches on [harvesting falcons on] a sustainable basis, the... officials make all possible efforts to make the Saker the rarest bird in Kazakhstan."

The harvest of Saker Falcons for falconry has been underway in Mongolia for nearly two decades. In an interview with A. Bold, then chief ornithologist with the Mongolian Academy of Sciences (Academy) (Ulaanbaatar, 1 June 1994), I (DHE) learned that the Academy and the Mongolian Ministry of Nature (Ministry) were anxious to begin exporting Sakers. In November 1994, the Ministry made an agreement to allow Saudi Prince Mohammed bin Naif to trap and export 800 Sakers over 10 years (see also Badam 2001). Although we believe that a harvest of 80 juvenile birds per year would not be a population limiting drain on Mongolian Saker populations as they existed in 1994 and 1995, we learned that more such agreements were made and that adults as well as juveniles were routinely exported. For example, by 1996, the Academy had entered into a commercial contract with Kuwaiti scientists to help them capture and export 25 falcons per year for three years (P. Tsengeg, pers. comm., 17 July 1997). Photos of many of the birds shipped to Kuwait in 1996 revealed high proportions of adults. Known exports included 80 falcons in 1994, 80 in 1995, 20 in 1996, and 150 in 1997 (Shijirmaa et al. 2000). However, Badam (2001), also of the Ministry, gave somewhat different values and reported that the Ministry has, since 1993, been allowing the removal of many birds for "research and commercial purposes" (Badam 2001:206), including Arab falconry.
A 1998 population survey of Saker Falcons in Mongolia (Shijirmaa et al. 2000) financed by the United Arab Emirates resulted in an estimate of 2823 pairs, high enough to encourage an expanded Saker harvest. However, the estimate was of questionable value, being based on a partial field season, covering an area only $1.1 \%$ of the land mass of Mongolia, and not allowing for the non-availability of nest support structures over most of the Saker habitat. The estimate was based on observations of only 46 pairs (Shagdarsuren et al. 2001), a 61fold extrapolation. S. Banzragch (2001), the Ministry official controlling trapping quotas, stated as early as 2000 that the Saker has been over-trapped across its range, and Fox (2002) concluded that "...most of the 7000-8000 Sakers reaching Arabia must be illegal..." More recently in Mongolia, licenses and exports included about 300 birds each year since 2001, and an illegal harvest is thought to be sizable and increasing (Gombobaatar et al. 2004).

Following our lead in creating 150 artificial nests from 1997-2000, other researchers have expanded efforts to offset the illegal harvest by experimenting with increasing Saker productivity and population size by building 250 artificial nest structures in nest-limited areas (Dixon et al. 2011). The experiment was expanded in 2009-2010 to include an additional 5,000 artificial nest structures. Careful study of patterns of nest occupancy on these structures compared with prey availability could shed additional light on Saker nomadism and its relationship with prey availability.

Other Threats.-Another factor that seems also to be limiting Saker populations locally is the use of inexpensive Chinese-made rodenticides (mostly bromadiolone: Gombobaatar et al. 2004) to save grass for cattle. Raptors, including Sakers, suffer secondary poisoning from consuming poisoned prey, but the extent of the problem in any particular area is unknown. Gombobaatar et al. (2004) believed that extirpation of Saker prey, primarily Brandt's Vole (Microtus branti), led to the 
elimination of the Saker as a breeding bird in two of his study areas.

Perhaps a greater long-term threat for the prey, and therefore for the Saker, are the sheep, shar, goats, horses, camels, yaks, and cattle. After five years of drought, in 2008, we found that above-ground portions of all palatable species of grass were absent across broad regions. It was possible to travel 50 or more $\mathrm{km}$ without finding an uneaten blade of grass. Only on inaccessible niches of cliffs were the palatable species visible. This dearth was reflected in observations of goats foraging in raptor nests consuming nesting materials, and our seeing the steppes strewn with dead grazing animals.

\section{ConClusions}

Raptor demographic studies typically use eyrie occupancy and productivity rates to determine endangered or threatened status of a species. For the Saker, such comparisons must henceforth be tempered on the expectation that local populations may be displaced as adults seek distant zones of prey abundance.

In future studies, it will be interesting to know how much of what we have come to accept as dramatic changes in raptor populations are explained, at least partially, by the tendency of raptors and even some predatory mammals to merely move elsewhere when food is scarce. There is much in the published literature (e.g., Watson 1977:140) to support this concept.

Despite drought, overgrazing, removal for falconry, and rodenticide use, the Saker still breeds regionally in good numbers in Mongolia, as evidenced by our finding 50 new breeding territories in 2008. Eyries are sometimes less than $3 \mathrm{~km}$ apart, and fledging rates, even in some areas devastated by overgrazing, are high.

For Saker populations to persist in Mongolia, conservation organizations should review and strive to limit falcon trafficking. It is also essential that we encourage the Mongolian government to curtail rodenticide use and to promote herd reduction during drought years. Changes in government policy could reduce local losses of adult and fledged Sakers due to electrocution (Harness et al. 2008) and loss of Saker clutches and broods due to periodic removal of nests.

Factors Favoring Nomadism.-When the feeding niche of an avian predator is narrow and largely dependant (at least seasonally) on irruptive prey species, nomadism is to be expected (Andersson 1980). Certain demographic traits accompany nomadism: these are low site fidelity rates, reduced territoriality, and greater flexibility in the types of nesting support structures chosen (if nest sites are limited). The Snowy (Bubo scandiaca) and Shorteared Owls (Asio flammeus), extreme examples of nomadic predators, overcome the nest availability problem by routinely nesting on the ground, and an area with many owls one year may have few or none the next. Similarly, one region of Mongolia may have a high Saker population one year, but, during a prey nadir, only a few Saker sites remain occupied. Unlike the owls, Sakers rarely nest on the ground (Ellis et al. 1997, Ellis 2001, Stubbe et al. 2010).

Why have other studies of the Saker, and its putative conspecific, the Gyrfalcon, not reported nomadism? Literature summaries note that for both falcons, breeding populations increase locally when prey is abundant (Cade 1982, Dement'ev and Gladkov 1966, Potapov and Sale 2005), but there is no mention that such concentrations involve immigrant breeders (true nomads). Mindell and White (1988) could not show that a Gyrfalcon population in Alaska underwent regular fluctuations, and Dement'ev and Gladkov (1966:108) explained that Gyrfalcon breeding populations are increased by immatures breeding early and by normally nonproductive adults, already resident in an area, breeding during prey irruptions. Clum and Cade (1994) reinforce the idea that Gyrfalcon adults remain 
Table 3. Raptor responses to food availability. ${ }^{1}$

\begin{tabular}{|c|c|c|}
\hline Food Availability & Raptor Response & Examples \\
\hline A. Food available year round & $\begin{array}{l}\text { Adults resident }{ }^{2} \text {; young disperse } \\
\text { but are nonmigratory }\end{array}$ & Most tropical raptors \\
\hline B. Food available only seasonally & Adults site tenacious but migratory & $\begin{array}{l}\text { Most boreal and temperate raptors; } \\
\text { some austral species }\end{array}$ \\
\hline $\begin{array}{l}\text { C. Food available with seasonal } \\
\text { highs in summer but available at } \\
\text { low levels in winter }\end{array}$ & Adults resident; juveniles migratory & $\begin{array}{l}\text { Peregrine Falcons breeding at low } \\
\text { latitudes }\end{array}$ \\
\hline $\begin{array}{l}\text { D. Sole food source eruptive/cyclic } \\
\text { over broad regions }\end{array}$ & Adults long distance nomadic & Snowy Owl, Short-eared Owl \\
\hline $\begin{array}{l}\text { E. Primary food source eruptive/cyclic } \\
\text { over broad regions, but secondary } \\
\text { foods dependable }\end{array}$ & $\begin{array}{l}\text { Adults site tenacious but population } \\
\text { breeding rate is low except during } \\
\text { prey eruptions }\end{array}$ & $\begin{array}{l}\text { Gyrfalcon, Rough-legged Hawk } \\
\text { (D/E intermediate), Boreal Owl } \\
\text { (Aegolius funereus) (D/E } \\
\text { intermediate with males site } \\
\text { tenacious and females nomadic) }\end{array}$ \\
\hline $\begin{array}{l}\text { F. Primary food source locally eruptive, } \\
\text { secondary foods locally dependable }\end{array}$ & $\begin{array}{l}\text { Most adults nomadic, some adults } \\
\text { (those at most favorable locations for } \\
\text { secondary food) site tenacious }\end{array}$ & Saker \\
\hline $\begin{array}{l}\text { G. Sole prey source or multi-source } \\
\text { all locally and simultaneously eruptive }\end{array}$ & All adults locally nomadic & Black Falcon \\
\hline $\begin{array}{l}\text { H. Multi- or single-source food over } \\
\text { abundant }\end{array}$ & Polygyny & Harriers (Circus sp.), Boreal Owl \\
\hline $\begin{array}{l}\text { I. Multi-source food, sparse or difficult } \\
\text { to acquire }\end{array}$ & Polyandry & $\begin{array}{l}\text { Harris' Hawk (Parabuteo } \\
\text { unicinctus), Galapagos Hawk } \\
\text { (Buteo galapagoensis) }\end{array}$ \\
\hline $\begin{array}{l}\text { J. Multi-source foods available } \\
\text { seasonally, supplemental sources } \\
\text { rarely and briefly eruptive }\end{array}$ & Large broods or multiple broods & $\begin{array}{l}\text { Golden Eagle (Aquila chrysaetos), } \\
\text { some kestrels (Falco sp.) }\end{array}$ \\
\hline
\end{tabular}

${ }^{1}$ Some species fit two or more classes (e.g., Peregrine Falcons sometimes fit B or C, and sometimes H).

${ }^{2}$ Resident-ornithological meaning is non-migratory, present in local area year round.

on territory, but do not breed when prey is scarce. However, nomadism is evidenced, not only by increases in a population in one area, but also by the simultaneous disappearance of a population in another area. Perhaps the clearest example of nomadism in large falcons is that of the Black Falcon of Australia (Table 3) where, in some areas, the breeding population disappears entirely when the prey moves to wet zones (Ferguson-Lees and Christie 2001). Similarly, Morozov (2011) gave us the clearest suggestion of nomadism in the Gyrfalcon. A small population of Gyrfalcons in northeastern European Russia underwent complete and multi-year disappearance following a severe crash of Willow Ptarmigan (Lagopus lagopus) populations. It seems likely that such prey population nadir events will become more common (and nomadism in Gyrfalcons more apparent) with the weather uncertainties attending global warming.

Table 3 presents a broad (but not all-inclusive) array of options for raptor populations when food abundance changes greatly. There we see that the Saker differs from the Gyrfalcon in the way food is distributed in the environment. The most likely explanation for the Saker population highs we found in some areas and nadirs in others is that rodent irruptions (or rodent extirpations) are localized, with the result that in Mongolia, many Saker adults 
must be nomadic. The Gyrfalcon is likely less nomadic because it depends on prey with cycles synchronized over huge areas, so nomadism would be non-productive. That is: falcons would likely fail to find far distant prey concentration zones, and to emigrate would be to jeopardize future occupancy of a territory. For the Gyrfalcon system (i.e., reduced breeding but no nomadism) to work, alternative prey must be available during prey nadir events. We know of only the one example (Morozov 2011) of probable nomadism in the Gyrfalcon. The Saker, when detecting a prey nadir, seems to have the proclivity to move to a region where prey is more abundant. Of course, breadth of foraging niches of the Saker and Gyrfalcon also influence the response, be it site tenacity, nomadism, or a mixture of the two. Unfortunately, recent anthropogenic mortality factors (especially the widespread use of rodenticides and the removal of birds for falconry) complicates our interpretation of the cause of population fluctuations.

Marking/banding or radiotelemetry studies should yield definitive answers to the questions posed in Table 3, but the observations that were once to us surprising and puzzling (e.g., asynchronous nesting, ground nesting, the use of unusual nest support structures, abandoned eggs, and many unoccupied eyries in some regions) are best explained by recognizing that many Sakers, like the herders of Mongolia, are nomadic.

\section{ACKNOWLEDGMENTS}

This article is dedicated to the memory of Dashnamjilyn Batdelger who suffered harassment and assault and was forced out of two, and perhaps three, professional positions because of his opposition to Mongolian Ministry of Nature policy on falcon exploitation. He died under mysterious circumstances on 9 February 2003.

Fieldwork in Mongolia in 1994, 1995, and 1998 was funded largely by the National Aero- nautics and Space Administration (NASA) with additional support from the Patuxent Wildlife Research Center. Some field expenses in 1995 were funded by NARC. The Union for the Conservation of Raptors and the Turner Wildlife Foundation funded the 1997 expedition to build artificial eyries. An anonymous donor and Smithsonian Magazine helped in 1998 , and the same anonymous donor financed our work in 2000 and 2008. The Institute for Raptor Studies provided equipment throughout.

Our expeditions were hosted by the Ministry in 1994 and 1998, in 1995 by the Mongolian State University, by the Academy in 1997, and in 2000 by the Academy of Chingges Khan. We thank the following, each of whom assisted for at least one full field season: P. Tsengeg, Merlin Ellis, Peter Whitlock, B. Chingis, and Adele Conover.

\section{Literature Cited}

Allen, C. R., And D. A. Saunders. 2002. Variability between scales: Predictors of nomadism in birds of an Australian Mediterranean-climate ecosystem. Ecosystems 5:348-359.

ANDERSSON, M. 1980. Nomadism and site tenacity as alternative reproductive tactics in birds. Journal of Animal Ecol. 49:175-184.

BADAM, K. 2001. CITES and sustainable use of Saker Falcon in Mongolia. Pages 202208 in S. Banzragch, O. Shagdarsuren, D. Sumiya, S. Gombobaatar, N. Fox, E. Potapov, F. Launay, T. Shiirevdamba, and D. Shijirmaa (Eds.). Proceedings of the II International Conference on the Saker Falcon and Houbara Bustard, Mongolia.

BANZRAGCH, S. 2001. Foreword. Pages 4-5 in

S. Banzragch, O. Shagdarsuren, D. Sumiya, S. Gombobaatar, N. Fox, E. Potapov, F. Launay, T. Shiirevdamba, and D. Shijirmaa (Eds.). Proceedings of the II International Conference on the Saker Falcon and Houbara Bustard, Mongolia.

BanzRAGCH, S., O. Shagdarsuren, D. SumiYa, S. GombobaAtar, N. Fox, E. Potapov, F. 


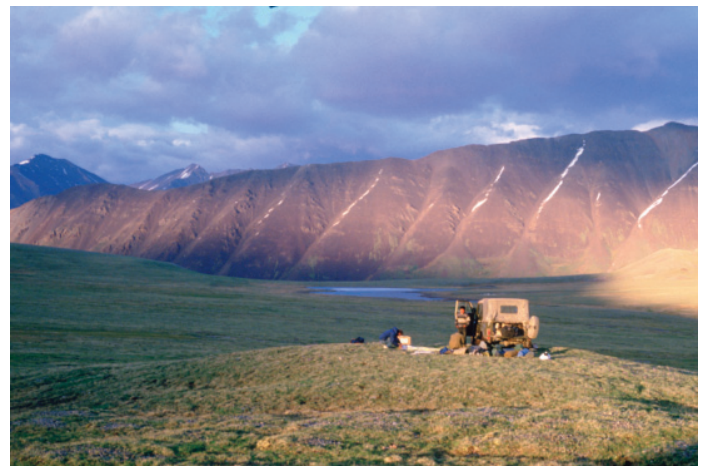

Figure 3. On six expeditions, each one of which involved a single 4WD vehicle, we searched for falcon and eagle eyries across Mongolia. Here we are camped in the Russian Altay Mountains in extreme northwestern Mongolia.

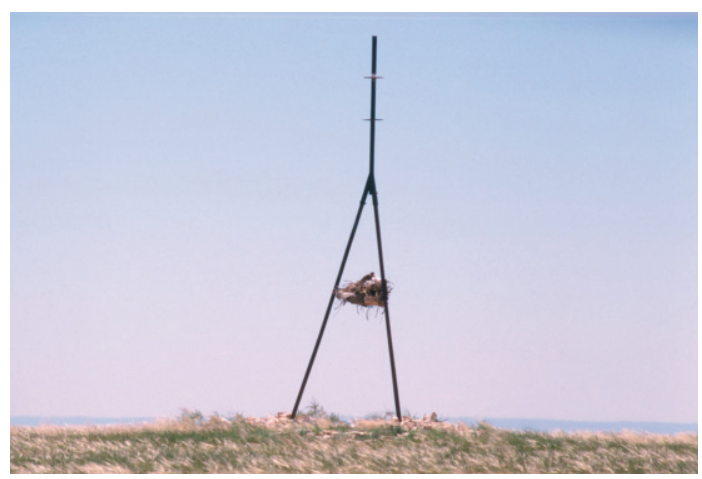

Figure 5. One of 150 artificial eyries constructed by our team from 1997-2000, an adult Saker incubates in 1998.

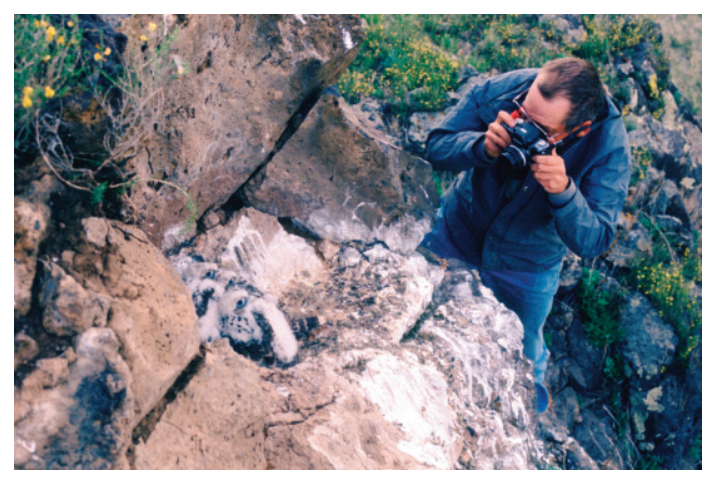

Figure 7. We created this ledge on a short cliff in southeastern Mongolia in 1997. It was already in use in 1998. Here, Jim Lish photographs the young.

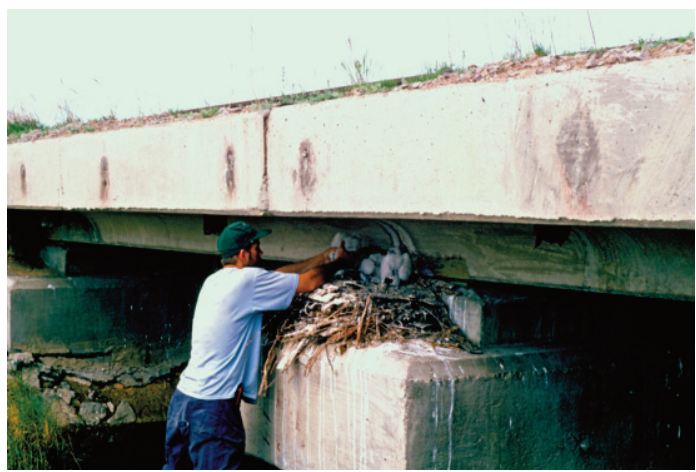

Figure 4. Sakers often nest on manmade structures: here a railroad bridge in northeastern Mongolia.

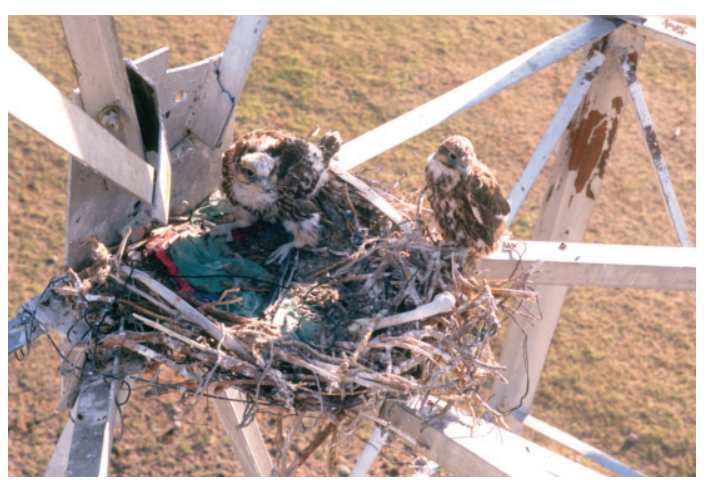

Figure 6. An artificial eyrie built in 1997 with nestling Sakers in 1998.

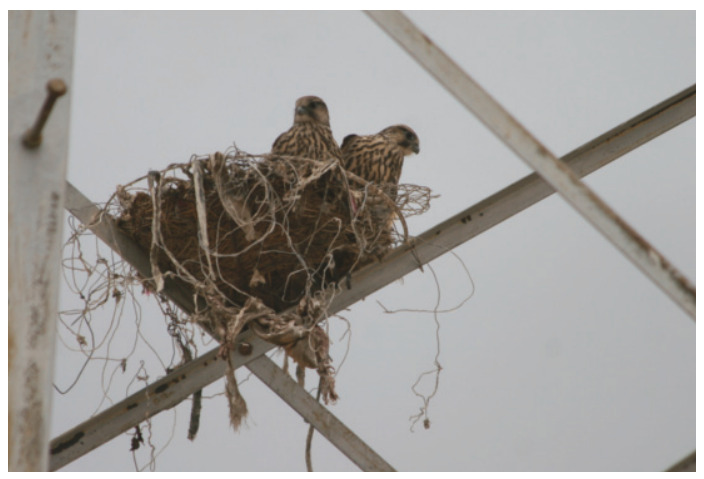

Figure 8. Almost all of the 80 artificial eyries built by my Mongolian helpers from 1998-2000 were seemingly unstable wire hoops on electric transmission pylons. However, nearly all were still in place in 2008. 
LAUnAY, T. ShiIREVDAmba, AND D. SHIJIRMAA (EDS.). 2001. Proceedings of the II International Conference on the Saker Falcon and Houbara Bustard, Mongolia.

BARTON, N. W. H. 2002. Recent data on Saker trapping pressure. Falco 20:5-8.

BAUMGART, W. 1978. Concerning plumage, status, and migration of breeding eastern Saker Falcons (Falco cherrug milvipes). [In German] Mitteilungen aus dem Zoologischen Museum (Berlin). 54 (Suppl., Ann. Orn. 2):145-166.

Baumgart, W. 1980. Der Sakerfalke. A. Ziemsen Verlag, Wittenberg Lutherstadt, Germany.

Bechard, M. J., ANd T. R. Swem. 2002. Rough-legged Hawk (Buteo lagopus). In A. Poole (Ed.). The Birds of North America Online. Ithaca: Cornell Lab of Ornithology; Retrieved from The Birds of North America Online database: http://bna.birds.cornell. edu.bnaproxy.birds.cornell.edu/bna/species 1641.

Bold, A., AND S. BoldBAATAR. 2001. Range, seasonal distribution, peak and decline of the Saker Falcon in Mongolia. Pages 155159 in S. Banzragch, O. Shagdarsuren, D. Sumiya, S. Gombobaatar, N. Fox, E. Potapov, F. Launay, T. Shiirevdamba, and D. Shijirmaa (Eds.). Proceedings of the II International Conference on the Saker Falcon and Houbara Bustard, Mongolia.

CAdE, T. J. 1982. The Falcons of the World. Cornell University Press, Ithaca, New York, USA.

CAde, T. J., J. H. Enderson, C. G. Thelander, AND C. M. White. 1988. Peregrine Falcon Populations: Their Management and Recovery. The Peregrine Fund, Boise, Idaho, USA.

Clark, R. J. 1975. A field study of the Shorteared Owl Asio flammeus Pontoppidan in North America. Wildlife Monograph 47:167.

Clum, N. J., AND T. J. CADE. 1994. Gyrfalcon (Falco rusticolus). In A. Poole (Ed.). The Birds of North America Online. Ithaca: Cornell Lab of Ornithology; Retrieved from The Birds of North America Online database: http://bna.birds.cornell.edu.bna proxy.birds.cornell.edu/bna/species/114

DEMENT'Ev, G. P., AND N. A. GladKov (EDs.). 1996. Birds of the Soviet Union, vol. 1. Israel Program for Scientific Translations, Jerusalem, Israel.

Dixon, A., N. Batbayar, G. Purev-Ochir, AND N. FoX. 2011. Developing a sustainable harvest of Saker Falcons (Falco cherrug) for falconry in Mongolia. In R. T. Watson, T. J. Cade, M. Fuller, G. Hunt, and E. Potapov (Eds.). Gyrfalcons and Ptarmigan in a Changing World. The Peregrine Fund, Boise, Idaho, USA. http://dx .doi.org/ 10.4080/gpcw.2011.0315

ELLIS, D. H. 2001. Recent history of Saker Falcon studies in Mongolia. Falco 17:5-6.

Ellis, D. H. 2010. The Institute for Raptor Studies expeditions in Mongolia, 19942000. Erforschung Biologischer Ressourcen der Mongolischen Volksrepublik (Halle/Saale) 11:189-212.

Ellis, D. H., T. Craig, E. Craig, S. PostupalSky, C. T. LaRue, R. W. Nelson, D. W. Anderson, C. J. Henny, J. Watson, B. A. Millsap, J. W. Dawson, K. L. Cole, E. M. Martin, A. Margalida, and P. Kung. 2009. Unusual raptor nests around the world. Journal of Raptor Research 43:175-198.

Ellis, D. H., M. H. Ellis, ANd P. TSENGEG. 1996. Productivity of Saker Falcons (Falco cherrug) in Mongolia. Pages 117-130 in Proceedings of the Specialist Workshop, Middle East Falcon Research Group, Abu Dhabi, UAE.

Ellis, D. H., M. H. Ellis, AND P. TSEnGeG. 1997. Remarkable Saker Falcon (Falco cherrug) breeding records for Mongolia. Journal of Raptor Research 31:234-240.

Ellis, D. H., P. TsEngeg, AND P. L. Whitlock. 1998. Saker Falcon research and conservation efforts in Mongolia, 1997. Falco 11:7.

Ellis, D. H., P. Tsengeg, P. L. Whitlock, J. W. Lish, D. B ATDELGER, AND A. CONOVER. 2001. Saker Falcons use artificial eyries in Mongolia. Newsletter of the World Work- 
ing Group on Birds of Prey and Owls 29/32:27-29.

Ellis, D. H., P. L. Whitlock, P. Tsengeg, AND R. W. Nelson. 1999. Siblicide, splayedtoes-flight display, and grappling in the Saker Falcon. Journal of Raptor Research 33:164-167.

Ferguson-Lees, J., AND D. A. Christie. 2001. Raptors of the World. Houghton Mifflin, New York, USA.

Fox, N. 2002. Developments in conservation of the Saker Falcon. Wingspan 11(2):9.

GaLushin, V. M. 1974. Synchronous fluctuations in populations of some raptors and their prey. Ibis 116:127-134.

GombobaAtar, S., D. Sumiya, O. ShagdarSUREN, E. PotAPOV, AND N. Fox. 2004. Saker Falcon (Falco cherrug milvipes Jerdon) mortality in central Mongolia and population threats. Mongolian Journal of Biological Sciences 2(2):13-21.

HARness, R., S. GombobaAtar, AND R. Yosef. 2008. Mongolian distribution power lines and raptor electrocutions. Paper No. 08 C1, 2008 Rural Electric Power Conference, Institute of Electrical and Electronics Engineers, New York, New York, USA.

Hickey, J. J., AND J. E. RoElle. 1969. Conference summary and conclusions. Pages 553-567 in J. J. Hickey (Ed.). Peregrine Falcon Populations: Their Biology and Decline. University of Wisconsin Press, Madison, Wisconsin, USA.

HIPKISS, T., B. HÖRNFELDT, Å. LUNDMARK, AND M. NorbÄCK. 2002. Sex ratio and age structure of nomadic Tengmalm's Owls: A molecular approach. Journal of Avian Biology 33:107-110.

Levin, A. S. 2000. Problems of Saker Falcon conservation in Kazakhstan. Falco 16:8-9.

LEVIN, A. S. 2001. On the critical state of the Saker Falcon population in Kazakhstan. Pages 64-79 in S. Banzragch, O. Shagdarsuren, D. Sumiya, S. Gombobaatar, N. Fox, E. Potapov, F. Launay, T. Shiirevdamba, and D. Shijirmaa (Eds.). Proceedings of the II International Conference on the Saker Falcon and Houbara Bustard, Mongolia.
Meyburg, B-U., And C. Meyburg. 1983. Vultures in Mongolia. Pages 99-106 in S. R. Wilbur and J. A. Jackson (Eds.). Vulture Biology and Management. University of California Press, Berkeley, California, USA.

Mindell, D. P., AND C. M. White. 1988. Fluctuations of observed breeding Roughlegged Hawks and Gyrfalcons: Regularity reconsidered. Oecologia 77:14-18.

Moritsch, M. Q. 1983. Photographic guide for aging nestling Prairie Falcons. BLM Snake River Birds of Prey Project, Boise District, Idaho, USA.

Morozov, V. V. 2011. Ecological basis for the distribution and breeding of Gyrfalcons in the tundra of European Russia and preconditions for spreading to new grounds. In $\mathrm{R}$. T. Watson, T. J. Cade, M. Fuller, G. Hunt, and E. Potapov (Eds.). Gyrfalcons and Ptarmigan in a Changing World. The Peregrine Fund, Boise, Idaho, USA. http:// dx.doi.org/10.4080/gpcw.2011.0222

Newton, I. 1979. Population Ecology of Raptors. Buteo Books, Vermillion, South Dakota, USA.

PARMelee, D. F. 1992. Snowy Owl (Bubo scandiacus). In A. Poole (Ed.). The Birds of North America Online. Ithaca: Cornell Lab of Ornithology; Retrieved from The Birds of North America Online database: http://bna.birds.cornell.edu.bnaproxy.birds. cornell.edu/bna/species/010

PIECHOCKI, R. 1983. Abriß der Erforschungsgeschichte der Avifauna mongolica. Erforschung Biologischer Ressourcen der Mongolischen Volksrepublik (Halle/Saale) 3:5-31.

Potapov, E., N. Fox, O. Shagdarsuren, D. Sumya, AND S. GombobaAtar. 2000. Home ranges of Saker Falcons in Mongolia. Falco 15:10-11.

Potapov, E., N. Fox, D. Sumya, And B. GomBOBAATAR. 2002. Migration studies of the Saker Falcon. Falco 19:3-4.

Potapov, E., N. Fox, D. Sumya, B. GomBobaAtar, F. LAUnAy, O. COMBreau, AND C. Eastham. 2001c. The Mongolian Saker 
Falcon: Migratory, nomadic or sedentary? Argos Newsletter 58:10-11, 16.

Potapov, E., N. C. Fox, D. Sumya, S. GomBOBAATAR, AND O. SHAGDARSUREN. 2001a. Nest site selection in Mongolian Sakers. Pages 132-137 in S. Banzragch, O. Shagdarsuren, D. Sumiya, S. Gombobaatar, N. Fox, E. Potapov, F. Launay, T. Shiirevdamba, and D. Shijirmaa (Eds.). Proceedings of the II International Conference on the Saker Falcon and Houbara Bustard, Mongolia.

Potapov, E., N. C. Fox, D. Sumya, S. GomBOBAATAR, AND O. SHAGDARSUREN. 2001b. Home ranges and habitat use of breeding Saker Falcons (Falco cherrug) in Mongolia. Pages 144-154 in S. Banzragch, O. Shagdarsuren, D. Sumiya, S. Gombobaatar, N. Fox, E. Potapov, F. Launay, T. Shiirevdamba, and D. Shijirmaa (Eds.). Proceedings of the II International Conference on the Saker Falcon and Houbara Bustard, Mongolia.

Potapov, E., AND R. Sale. 2005. The Gyrfalcon. Yale University Press, New Haven, Connectict, USA.

Shagdarsuren, O. 2000. A short history of Saker Falcon (Falco cherrug Gray 1834) studies in Mongolia. Falco 16:3-5.

Shagdarsuren, O., D. Sumya, S. GomBOBAATAR, E. PotAPOV, AND N. Fox. 2001. Saker Falcon in Mongolia: Numbers and distribution. Pages 25-33 in S. Banzragch, O. Shagdarsuren, D. Sumiya, S. Gombobaatar, N. Fox, E. Potapov, F. Launay, T. Shiirevdamba, and D. Shijirmaa (Eds.). Proceedings of the II International Conference on the Saker Falcon and Houbara Bustard, Mongolia.

Shijirmaa, D., E. Potapov, S. Banzragch, AND N. C. Fox. 2000. The Saker Falcon Falco cherrug in Mongolia. Pages 263-268 in R. D. Chancellor and B.-U. Meyburg
(Eds.). Raptors at Risk. Proceedings of the 5th World Conference on Birds of Prey and Owls (1998), Midrand, South Africa. WWGBP/Hancock House, Blaine, Washington, USA.

Stubbe, M., A. Stubbe, N. Batsajchan, S. GombobaAtar, T. Stenzel, H. VON WEHRDEN, S. BoldBAATAR, B. NyAMBAYAR, D. SumjaA, R. SamjaA, N. Ceveenmuadag, AND A. BolD. Brutareale und Brutbiologie der Greifvogelarten der Mongolei. Erforschung Biologischer Ressourcen der Mongolischen Volksrepublik (Halle-Saale) 11:23-175.

Sumiya, D., S. GombobaAtar, O. ShagdarSUREN, E. PotAPOV, AND N. Fox. 2001. Wintering of the Saker Falcon in Mongolia. Pages 138-143 in S. Banzragch, O. Shagdarsuren, D. Sumiya, S. Gombobaatar, N. Fox, E. Potapov, F. Launay, T. Shiirevdamba, and D. Shijirmaa (Eds.). Proceedings of the II International Conference on the Saker Falcon and Houbara Bustard, Mongolia.

UptON, R. 2002. Arab Falconry: History of a Way of Life. Hancock House, Blaine, Washington, USA.

Watson, D. 1977. The Hen Harrier. T. \& A. D. Poyser, Berkhamsted, Hertfordshire, UK.

WhitaKer, D. M., W. A. MonteVecchi, AND J. W. Goose. 1996. Breeding season irruptions of Rough-legged Hawks (Buteo lagopus) on insular Newfoundland. Arctic 49:306-310.

Wiggins, D. A., D. W. Holt, AND S. M. LEASURE. 2006. Short-eared Owl (Asio flammeus). In A. Poole (Ed.). The Birds of North America Online. Ithaca: Cornell Lab of Ornithology; Retrieved from The Birds of North America Online database: http://bna.birds.cornell.edu.bnaproxy.birds. cornell.edu/bna/species/062 